\begin{tabular}{|c|c|c|}
\hline & This Journal is available in Telkom University online Journals & ::::::::::: \\
\hline & Jurnal Manajemen Indonesia & 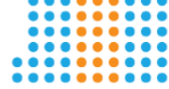 \\
\hline Telkom & Journal homepage: journals.telkomuniversity.ac.id/ijm & $\begin{array}{l}\text { JURNAL } \\
\text { MANAJEMEN } \\
\text { INDONESIA }\end{array}$ \\
\hline
\end{tabular}

\title{
Performance Management Practices in Science Technology Parks: Case Study of Bandung Techno Park
}

\author{
Kiki Sudiana and Ratih Hendayani \\ School of Economics and Business, Telkom University, Bandung, Indonesia
}

\begin{abstract}
The primary objective of developing science and technology parks (STPs) is to foster knowledge-based economic clusters in an area. Such economic clusters play an important role in encouraging regional innovation and competitiveness to increase the contribution of science and technology to economic development. Due to the important role of the clusters in economic development, effectively managing their performance is essential. The purpose of this paper is to study the performance management practices and key performance indicators (KPIs) implemented in Bandung Techno Park (BTP), one of the leading techno parks in Indonesia, through the literature review method. This research revealed that a number of standard or similar KPIs are widely used in many STPs, such as the number of startups created, the level of economic development generated, and the number of innovative products made. The study also proposed two additional performance indicators for BTP to complete its goals: economy generated in the area and profitability of the STP. The contribution of this research is to provide BTP with a reference for evaluating its organizational performance through the use of standard KPIs. Future research can use standardized KPIs, which have been validated with a quantitative approach, to investigate and evaluate organizational performance.
\end{abstract}

Keywords-Performance management; Key Performance Indicators; Science and Technology Parks

\begin{abstract}
Abstrak
Tujuan utama pengembangan Science Technology Parks (STP) atau Taman Sains dan Teknologi (KST) adalah untuk menumbuhkembangkan klaster-klaster ekonomi berbasis pengetahuan di suatu daerah. Klaster ekonomi berbasis pengetahuan tersebut memainkan peranan penting dalam mendorong inovasi dan daya saing daerah untuk meningkatkan kontribusi sains dan teknologi dalam perkembangan ekonomi. Terkait dengan pentingnya peranan klaster tersebut dalam perkembangan ekonomi, maka penting untuk mengatur kinerjanya secara serius. Tujuan dari paper ini adalah untuk mempelajari Praktik Manajemen Kinerja dan juga Indikator Kinerja Utama, yang dipergunakan oleh Bandung Techno Park (BTP) sebagai salah satu Technopark terkemuka di Indonesia. Studi ini menggunakan metode tinjauan literatur. Dari studi tersebut terungkap bahwa ada kesamaan KPI dari yang telah digunakan pada berbagai STP, seperti jumlah startups yang tumbuh, perkembangan ekonomi, jumlah produk-produk inovatif yang diciptakan dan juga menawarkan dua indikator kinerja tambahan bagi BTP untuk menyempurnakan tujuannya, yang adalah: ekonomi yang dihasilkan pada daerah dan profitabilitas STP. Manfaat dan kontribusi, Memberikan acuan kepada STP BTP sebuah acuan standar KPI yang dapat digunakan untuk mengevaluasi kinerja organisasi. Penelitian selanjutnya, Dapat menggunakan KPI yang sudah di bentuk untk mengevaluasi dan menggunakan pendekatan kuantitatif untuk memvalidasi KPI yang terbentuk.
\end{abstract}

Kata Kunci - Indikator Kinerja Utama, Manajemen Kinerja, Taman Sains dan Teknologi

\section{INTRODUCTION}

The area of science and technology parks (STPs) is believed to be one of the strong instruments that aim to improve regional economic development and enhance regional competitiveness through developing knowledgebased economic clusters. Such areas are ideal locations for developing new technology-based companies, creating jobs, and increasing economic development (Fukugawa, 2006; Monck \& Peters, 2009; Yan \& Chien, 
2013). In the era of President Joko Widodo, the Government of the Republic of Indonesia has decided to build 100 STPs. The aim is to generate new economic centers in many areas through the creation and development of new startups and research-based companies. Such a program also intends to bridge knowledge into business activities (Ministry of Research, Technology and Higher Education Republic of Indonesia, 2015).

As most of the STPs are funded with public or state funds, determining whether each STP can function based on its intended purpose is important. It is also interesting to study the performance management practices of one of the leading STPs in Indonesia, considering that good STP performance management will ensure that the STPs carry out their ideal mission while ensuring the achievement of each company's goals (Mathews, 2011). Discussions about performance management are also important in providing STP management with an understanding of how to manage, and improve organizational effectiveness and performance (Cardy \& Leonard, 2011).

In addition to integration, there are other aspects that greatly affect success in managing the performance of organizations, groups, and individuals. Performance is a condition wherein certain parties must recognize and know how far the organization's vision has been achieved and determine the impact of operational policies taken. Management can use performance as a benchmark for periodic assessments relating to the operational effectiveness of the entire organization, parts of the organization, and its employees on the basis of existing targets, standards, and criteria (Listiani, 2011).

Key performance indicators (KPIs) are an important element in STP performance management. KPIs are benchmarks of performance agreed to be achieved. Thus, they can be considered as indicators of whether the STP has done what it should and achieved the targets set. Several studies and reports on various KPIs from several STPs have been conducted throughout the world, but no research has been found on STP performance management practices in Indonesia. Thus, the current study aims to review and summarize existing studies on KPIs and discuss performance management practices in Bandung Techno Park (BTP) as one of the leading STPs in Indonesia.

\section{LITERATURE REVIEW}

\section{A. Science and Technology Parks}

The mission and nature of STPs can be more easily understood by looking at the definitions. The following are some STP definitions taken from some of the world's leading associations.

According to the UKSPA, "STP is an effort to facilitate business and technology transfers, which:

1. Encourages and supports startups and business incubation to create innovations, high growth, and knowledge development.

2. Provides an environment, in which larger and global businesses can develop specific and close relationships with certain centers of knowledge innovation (centers of knowledge) for mutual benefit.

3. Has formal and operational links with knowledge innovation centers such as universities, tertiary institutions and research organizations."

According to the International Association of Science Parks (IASP), STP is an organization governed by specialist professionals, whose main purpose is to increase the prosperity of the community by promoting a culture of innovation and competitiveness of related businesses and knowledge-based institutions. To achieve its goals, the STP has the following functions:

1. Stimulates and manages the flow of knowledge and technology among universities, research and development (R\&D) institutions, companies, and markets;

2. Facilitates the creation and growth of innovation-based companies through an incubation and spin-off process; and

3. Provides other value-added services accompanied by the provision of high-quality space and facilities" (IASP, 2016).

STPs are geographical areas with a group of buildings prepared for various entrepreneurial firms. In general, STPs are research- and science-oriented with a variety of resources or services provided in them. This may include facilitating the creation of technology licenses, organizing trade shows, providing funds for 
commercialization, and/or distributing and disseminating information about R\&D activities from tenants (Cumming \& Johan, 2013).

The Association of University Research Parks (AURP) defines University Research Parks as property-based businesses with the following functions:

a. Design master plans for research and commercialization;

b. Create partnerships between businesses and universities and research institutions;

c. Encourage the growth of new companies;

d. Downstream and commercialize technology; and

e. Encourage economic development based on technology."

After summarizing the various definitions taken from several STP associations and the additional papers above, the following is a summary of the various roles of STPs. Some of the instructions below provide guidance on the STPs' ideal roles.

Table 1. The Roles of STP

\begin{tabular}{|c|c|c|}
\hline No. & Role & Reference \\
\hline 1 & $\begin{array}{l}\text { To facilitate and encourage the creation of } \\
\text { innovative/knowledge-based startups }\end{array}$ & $\begin{array}{l}\text { (UKSPA 2016), (IASP 2016), (AUSP 2016), } \\
\text { (European Commission 2016), (Vilà \& Pagès, } \\
\text { 2008), (Koh, Koh, \& Tschang, 2005) }\end{array}$ \\
\hline 2 & $\begin{array}{l}\text { To support the development of all startups through } \\
\text { training, coaching, mentoring and incubation programs }\end{array}$ & $\begin{array}{l}\text { UKSPA 2016), (IASP 2016), (AUSP 2016), } \\
\text { (European Commission 2016), (Vilà \& Pagès, } \\
\text { 2008), (Koh et al., 2005) }\end{array}$ \\
\hline 3 & $\begin{array}{l}\text { To stimulate the development of innovative products by } \\
\text { facilitating research to develop commercial products }\end{array}$ & (Koh et al., 2005) \\
\hline 4 & $\begin{array}{l}\text { To accelerate the growth of small and medium-sized } \\
\text { companies in techno parks through networking, } \\
\text { partnerships, and innovation }\end{array}$ & $\begin{array}{l}\text { (UKSPA 2016), (IASP 2016), (AUSP 2016), } \\
\text { (European Commission 2016), (Vilà \& Pagès, } \\
\text { 2008), (Koh et al., 2005), (Nargesi, Esfeden, } \\
\text { \& Nargesi, 2014) }\end{array}$ \\
\hline 5 & $\begin{array}{l}\text { To facilitate the internationalization of companies in } \\
\text { their scope }\end{array}$ & (IASP 2016) \\
\hline 6 & $\begin{array}{l}\text { To provide an environment that fosters a culture of } \\
\text { innovation, creativity, and quality }\end{array}$ & (IASP 2016) \\
\hline 7 & $\begin{array}{l}\text { To attract more investment into knowledge-based } \\
\text { businesses }\end{array}$ & (European Commission 2016) \\
\hline 8 & To act as a catalyst for regional economic development & (Koh et al., 2005) \\
\hline
\end{tabular}

\section{B. Performance Management of STPs}

"Performance management" can be defined as the process of realizing an explanation of what to achieve, how to achieve it, and what approach to use in managing people to increase opportunities to achieve work related results (Baharun, 2016). Performance management ensures that the goals, mission, and values of the organization can be achieved well through good communication between the leaders and subordinates. Thus, sustainability in providing mission information, values, and organizational goals can be achieved (Listiani, 2011).

There are at least three main reasons why it is important to clearly manage and evaluate STP performance and its implications for the economy. First, because STPs are often financially supported by governments or the public sector, which use them as their agents to develop the local economy, each STP must be responsible for their activities, and their expenditures must always be transparent (Monck \& Peters, 2009). In addition, private sector stakeholders also need clear benchmarks regarding their return on investment. The second reason is that STPs must be able to show the outside world, either directly or through the media, how effective they are. The image of success plays a key role in attracting more tenants and talented people who will work for these tenants, building local support, and fostering an understanding of STP activities. Finally, performance appraisal, as in 
almost all profit-oriented business cases, is important for managers and stakeholders in developing STP models and objectives as well as correcting any deficiencies.

Although most STP managers have collected and published general statistical information about the progress of their organization (number of companies, occupied area, total employment, etc.), only a few provide a general approach to STP performance monitoring and full evaluation. Many of these analyses compared the performance of companies operating in the STP (on-park) area with companies that do not have offices in the STP (off-park) area. They assessed whether there are statistically important differences regarding the various jobs created, sales, profitability, R\&D output, new products and services, company survival rates, and so on between these two types of firms (Monck \& Peters, 2009). Yin (1994) also highlighted that the reasons for conducting case studies include explaining the cause and effect relationship, describing various phenomena in their specific contexts, exploring problems or questions, and so on (Yin, 1994).

\section{RESEARCH METHODOLOGY}

This is a desk research in which the investigation is based on publications relevant to the STP area. The focus of the research will be on documents originating from the main factors that triggered the creation and development of STP areas: shared workspaces, accelerators, journals, associations, and government agencies. In the first stage, the analysis is carried out on data obtained from research in the STP area, information collected from the desk research, and expert research, which are supported by the conceptual basis proposed in the research bibliography. In the next stage of the analysis, obstacles in performance management are the main practices adopted as well as the methods and tools used. In other words, desk research analyzes the relationship between the maturity of the STP area and its performance management (Olivia \& Kotabe, 2019).

The current study uses a secondary research review involving a summary, examination and/or synthesis of previous research in which data were collected from studying 12 papers and 3 reference guides from world-class STP associations. In addition, it will also discuss the KPI practices and performance management at BTP. In terms of data collection, this secondary study uses two types of data collection. The first includes internal secondary data, which consist of information collected from research companies (in this case, BTP). The second one involves external secondary data, which consist of information collected from outside the research company, such as papers, reports, and the official STP website.

\section{RESULTS AND DisCUSSIONS}

\section{A. KPI Benchmarks of World-Class STPs}

Manchester Techno Park

In October 2010, the IASP held a workshop, which was organized by Manchester Science Park. A working group discussed relevant KPIs for STPs. The participants of this working group were the STP management representatives from the IASP members. The outcome of this group effort is a list of indicators/KPIs, which can be used as a reference for STP managers. The workshop indicator list is divided into four perspectives: the commercial industry, stakeholders, image and reputation, and internal business processes.

Table 2. List of Manchester Techno Park's KPIs

\begin{tabular}{lll}
\hline Perspective & Performance Indicator & \multicolumn{1}{c}{ Size } \\
\hline Commercial & Profitability & Profit before interest and taxes -\% of the budget \\
& $\%$ Occupancy rate & Sq. ft. occupied/net sq. ft. \\
& Sales & External inquiries/conversion rate (amount per year) \\
& Debt Management & Total aged debt $>120$ days (average 12M before) \\
& $\begin{array}{l}\text { Financial performance cf } \\
\text { budget } \\
\text { Increase in external } \\
\text { funding }\end{array}$ & Recovery of service fees (excluding voids and subsidies) \\
& Number of applications/funds received
\end{tabular}


Return on investment

Stakeholder Perspective

Innovation support

Company growth

Company Innovation Profile

Quality of Tenants

Environment, carbon footprint

Health and safety standards

Brand and Reputation

Media coverage

Accurate communication of techno park goals

International profile

Size of the techno park community

References from other organizations

Internal

Business

Processes
Internal rate of return (IRR)

Rental renewals and expansion as \% of total expiration (total expiries)

Participation in networking events (number of companies per year)

Inter-company trade (number of companies), link to knowledge base (number of companies), additional business/funding as a result of techno park intervention

$\%$ of university spin-outs/startups (vs total number of tenants), $\%$ of tenant companies that grew (jobs), $\%$ of tenant companies that grew (turnover), $\%$ of tenant companies that grew (exports), $\%$ of tenant companies that grew (investments external), the survival rate of existing tenants in the techno park

$\%$ of graduates in the techno park, number of products/services developed by tenants, number of patents exploited by tenants, number of products licensed inside and out,

$\%$ of companies investing in research and development, \% of tenant companies outsourcing research activities (Open Innovation)

Average salary paid at the techno park vs. average salaries at the national/regional level, $\%$ of tenants who fully meet the techno park's entry criteria, \% of tenants who are given awards for achievement, number of publications issued by tenants, $\%$ of employees at the techno park who have postgraduate degrees, \% of investment companies in the techno park (inward investment companies)

Reducing paper usage, reducing public waste collection, increasing recycling, and reducing utility consumption

Number of incidents that can be prevented (No of preventable incidents)

Coverage received (pieced of coverage received)

$\%$ annual inquiries from the right company

Number of qualified invitations to speak or participate in seminars and study requests, visits that can be a benchmark

The number of companies in the techno park network

$\%$ inquiries from references

Staff turnover-average 3 years before, sick staff absentee level-employee days/average, Number of training sessions - average number/employee, number of personal development opportunities - average/employee

Timely communication of

Number of credit notes issued

accurate information

Error log service level

Repaired within 48 hours

Effective security services

Number of security incidents, response to incidents $<15 \mathrm{~min}$

Reliable IT system

Total outages of ITC operations that last $>3$ hours 
The above is a long, detailed, and comprehensive list of KPIs. However, according to a study conducted by PricewaterhouseCoopers (2007), the effective number of KPIs is between 4 and 10. Thus, not all of the above indicators must be included in the KPIs of an STP. STP management must be careful in choosing relevant KPIs to be included in the contract and its respective mission.

\section{$\underline{\text { KPI Benchmarks of European Commission Documents, } 2013}$}

A European Union institution, the European Commission conducted a study in 2013 and produced a guidance document for the establishment of science and technology parks for the European Union entitled: Setting up, Managing and Evaluating EU Science and Technology Parks, an Advice and Guidance Report on Good Practice. Some STP performance measures described in the document include the following:

1) Land area (in hectares), available building land (m2). This is a simple KPI only suitable for newly established STPs.

2) The number of companies located in STP and the number of their employees. In particular, the number of skilled workers can be expanded into several segments, such as energy operators/technicians, engineers, and research and management personnel.

3) Number of companies that succeeded/graduated from STP (along with the number of their employees).

4) Income from renting out and providing other services annually (and their growth).

5) The type and quality of services provided by the STP to support tenant operational activities, such as Internet, telephone, meeting rooms, administrative support, network events, virtual office services, accommodation, canteen, etc. The above services can be paid or provided for free for the tenants.

6) Number and types of external support services available at the STP to support the tenants' businesses, such as bookkeeping, mentoring, graphic design, printing, marketing consultants, public relations consultants, legal/patent consultants, etc. These services can be provided free of charge by the STP management or provided professionally by other companies as third-party partners.

7) Amount of capital a tenant can obtain either from a bank, government/private/state assistance, or from other investors, such as a venture capital company.

8) Number of new companies established in the local area (but outside STP) as a result of their collaboration with STP tenants.

\section{$\underline{\text { KPI of Multimedia Super Corridor, Malaysia }}$}

Multimedia Super Corridor (MSC Malaysia) is a leading information and communication technology (ICT) cluster in Malaysia, which is designed to attract world-class technology companies while developing the local ICT industry. This institution is fully supported by the Malaysian Government. Tenant companies at MSC Malaysia are grouped into four industry segments, representing four main ICT focus areas: the Information Technology Cluster (InfoTech), Creative Multimedia Cluster (CMC), Global Procurement Cluster (GSC), and Higher Education Institutions and Incubators (Yigitcanlar \& Sarimin, 2015).

The MSC Malaysia annual report from 2010 to 2015 clearly states the nine MSC Malaysia performance indicators: number of companies, jobs created, sales, exports, R\&D expenditures.

MSC Malaysia measures its success from the growth of various indicators and publishes these indicators in their industry's annual reports. Below is a summary of the MSC KPI achievements from 2006 to 2015 , as summarized from the MSC industry annual report.

Table 3. Achievements of MSC KPIs, 1997-2006

\begin{tabular}{lrrrrr}
\hline \multicolumn{1}{c}{ Performance Indicator } & 2011 & 2012 & 2013 & 2014 & 2015 \\
\hline Total number of companies & 2954 & 3167 & 3403 & 3632 & 3881 \\
Work created & 119138 & 128850 & 138071 & 147568 & 158549 \\
& & & & & \\
Sales (in billion RM) & 31.73 & 33.53 & 34.55 & 38.52 & 42.10 \\
Export Sales (in billion RM) & 10.12 & 11.55 & 12.41 & 13.73 & 16.16 \\
R\&D expenditure (million RM) & 1588 & 1.64 & 1.40 & 1.67 & 2.01 \\
\hline
\end{tabular}

Source: MSC annual report, 2010 and 2015

From the various indicators above, we can see how MSC supports the development of the latest high-tech businesses, provides the right facilities for them to conduct research, and supports them to develop the business. 
These indicators represent the MSC cluster's contribution to the growth of Malaysia's regional and national knowledge-based economy.

\section{B. The Role and Framework of STP KPIs}

The results of a review of the role of an STP are followed up by mapping out the existing KPIs that we integrated into the relevant role framework. The results of role mapping and KPIs are illustrated in the following table.

Table 4. KPI Mapping of an STP

\begin{tabular}{|c|c|c|}
\hline No & Role & Implementation of Relevant KPIs and Relevant STP \\
\hline 1 & $\begin{array}{l}\text { To facilitate and encourage the creation of } \\
\text { innovative/knowledge-based startups }\end{array}$ & $\begin{array}{l}\text { Number of startups (BTP, Manchester Techno parks, } \\
\text { European Union Documents) }\end{array}$ \\
\hline 2 & $\begin{array}{l}\text { To support the development of all startups through } \\
\text { training, coaching, mentoring, and incubation programs }\end{array}$ & $\begin{array}{l}\text { Training, coaching, mentoring and incubation programs } \\
\text { (BTP, Manchester Techno parks, European Union } \\
\text { Documents) }\end{array}$ \\
\hline 3 & $\begin{array}{l}\text { To stimulate the development of creative products by } \\
\text { facilitating research to develop commercial products }\end{array}$ & $\begin{array}{l}\text { R\&D expenditure (MSC), Number of products/services } \\
\text { developed by tenants, New Product Launches (Manchester } \\
\text { Techno parks, BTP) }\end{array}$ \\
\hline 4 & $\begin{array}{l}\text { To accelerate the growth of small and medium-sized } \\
\text { companies in STP through networking and innovation }\end{array}$ & Number of partnerships (BTP, Manchester Techno parks) \\
\hline 5 & $\begin{array}{l}\text { To facilitate the internationalization of companies } \\
\text { within the scope of the STP }\end{array}$ & Export sales (MSC, Manchester Techno parks) \\
\hline 6 & $\begin{array}{l}\text { To provide an environment that fosters a culture of } \\
\text { innovation, creativity, and quality }\end{array}$ & $\begin{array}{l}\text { Tenant or consumer satisfaction (BTP, Manchester Techno } \\
\text { parks, EU Documents) }\end{array}$ \\
\hline 7 & To attract more knowledge-based business investments & $\begin{array}{l}\text { Number of companies (MSC, BTP, Manchester Techno } \\
\text { parks, EU Documents) }\end{array}$ \\
\hline 9 & To act as a catalyst for regional economic development & Sales (MSC, Manchester Techno parks, BTP) \\
\hline
\end{tabular}

\section{Performance Management Practices in BTP}

Since the beginning of its operations, BTP's performance indicators have been carried out through the performance management process. BTP has several key indicators and performance targets. These KPIs are indicated in a management contract signed by the Director of the BTP and the Chair of the Telkom Foundation. Their achievements are evaluated every three months.

The KPI design of the BTP reflects the main output of each process and the final output is also the main business of the BTP. The BTP's main business processes reflect two important aspects of the tenant's R\&D efforts depicted in the flowchart in Figure 1.

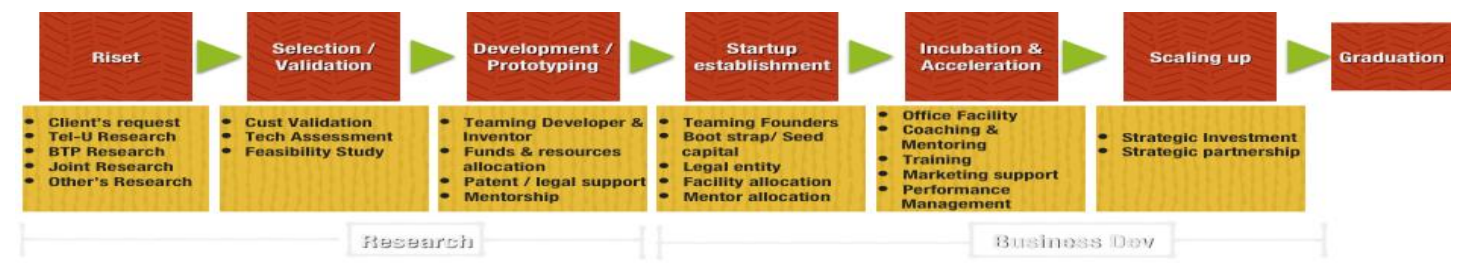

Figure. 1. Core Business Process of BTP (Source: BTP internal document, 2020) 
The final output from the STP and the process flow above is translated into a number of KPIs, which are then arranged according to the concept of a balanced score card. These KPIs are divided into four perspectives: Finance, Customers, Internal Business Processes, and Learning and Growth perspectives. The BTP's KPI set is shown in Table 5 below.

Table 5. BTP's KPIs

\begin{tabular}{ll}
\hline Perspective and Weight & Indicator \\
\hline Finance (25\%) & BTP Income (Rp) \\
& BTP Operating Ratio (\%) \\
Customer (25\%) & Number of tenants \\
& Consumer satisfaction index (\%) \\
& Number of contracts and agreements \\
Government assistance received & \\
Internal Business Processes (50\%) & Number of Public training sessions \\
& Number of startup teams (incubatee) \\
& Number of products validated \\
& Products launched \\
& Number of spin-offs \\
& Number of partnerships \\
& Training of internal personnel \\
Learning and Growth (5\%) & Registered IP \\
\hline
\end{tabular}

Source: BTP internal documents, 2020

Each indicator has a target (quantitatively) and becomes a BTP performance contract signed by the BTP Director and Chairman of the Telkom Foundation as the supervisor of the BTP Director. This performance target is evaluated quarterly.

Then, the performance score will be the basis of one take home pay component for the next three months. The basis of the assessment uses the weighted average method.

As the BTP managers are aware that techno park aim to be a center of innovation, Telkom Foundation management, which has a higher level than BTP management, gives more weight to research, product development, and startup creation. In a balanced scorecard, these are included in the internal business process perspective.

This performance management system is linked to the salary system; in other words, BTP's performance score in one quarter determines the amount of salary that BTP employees take home for the next quarter. Therefore, this system certainly encourages BTP staff and management to work together to achieve contracted targets.

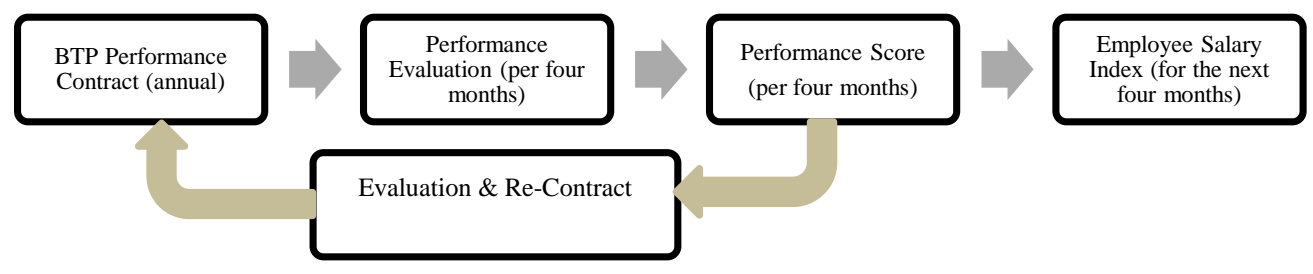

Figure. 2. Performance Management Process in BTP

\section{New Indicators Proposed for BTP}

The BTP's KPIs appear to be comprehensive using a balanced scorecard framework, a framework that is claimed to be comprehensive and balanced, and has an emphasis on long-term business sustainability if it incorporates learning and growth perspectives in its KPIs (Kaplan, 2010). However, BTP KPIs have not shown 
the most ideal output from existing techno parks, so additional KPIs are required indicating the sustainability of BTP as a private STP, namely, (1) economic development in the techno park area and (2) BTP profitability.

Regional economic development reflects the economic contribution of the existence of STP in the area. In this case, it refers to the impact of an STP, as a business group, on economic development. This indicator can be represented in the form of turnover or income from all economic actors in the region, including startup companies and industries based in the region. The data for this indicator can be obtained from the annual economic census conducted by BTP as the cluster manager. The increase in income from time to time reflects the economic development contributed by the STP.

Furthermore, as the BTP is a private techno park whose routine operational costs are not subsidized, the BTP must develop the ability to finance its own operations on an ongoing basis. The most important requirement to be able to survive without government subsidies is to ensure that the BTP has adequate profitability. In other words, the revenue generated is greater than its operational costs. Therefore, the second important indicator that needs to be included is profitability, and it needs to be reflected in the performance management arrangements.

\section{CONCLUSION AND SUGGESTION}

BTP must have a standard KPI reference that it must use in evaluating its organizational performance. Assessment is a mandatory procedure to be performed in determining employee performance to improve company performance. Such assessments are commonly called KPIs, which are used as a reference in measuring employee and company performance clearly and periodically. A large or small organization must have clear targets, so that the organization can run the business in the right direction. Apart from the organization, employees must also have targets in their work so that they can collectively achieve the organization's targets. KPIs are widely used by companies as a tool to measure employee performance levels based on their strategic and operational objectives. In addition, KPIs can also be used as benchmarks to determine business quality. KPIs are useful for monitoring, analyzing, and helping companies achieve success through the regulatory process. Standard KPIs can be used for evaluation, and a quantitative approach can be used to validate the formulated KPIs.

Managing the performance of an STP is very important in ensuring that all members of the management team and staff play their role ideally to achieve the target. Managing STP performance means setting performance targets, measuring performance, providing feedback, and intervening to ensure STP reaches its targets; it also links performance with other organizational systems (such as Remuneration). At this point, controlling STP performance is crucial because it allows management at a higher level to monitor performance against STP goals, intervene when goals are not met, and take corrective action.

There are several common KPIs among various STPs, such as the number of startups and companies in the techno park; the training, coaching, mentoring, and incubation programs that take place at the techno park; R\&D expenses; the number of products/services developed by tenants; new product launches, number of partnerships, sales exports, tenant or customer satisfaction, and tenant sales volume. The KPIs show the efforts made by STP and its real contribution to regional economic growth as the final result.

Performance management practices at the BTP, as one of the leading STPs in Indonesia, reflect that they have played most of their roles as an ideal STP and have shown almost ideal indicators. Performance management is also carried out online and is regularly reviewed. This system has a good impact on the salary system for all BTP employees, because this system is simple, easy to manage, and is effective in motivating employees to do their best to achieve common goals.

However, to achieve the ideal goal and ensure its sustainability, the authors propose two additional important indicators for STPs: (1) economic development in the techno park area and (2) techno park profitability. For further research, future studies must determine the right KPIs for the organization they are building, because the conditions may be different from other organizations. Such studies must ensure that they have checked as many KPIs as possible before using them to evaluate an STP, and use a quantitative approach to validate the formulated KPIs. At this point, future STPs must also determine that KPI targets will help them in better understanding and fulfilling their goals, and then integrate them into the entire department. Finally, KPIs must be consistent with their strategy of running the organization. 


\section{REFERENCES}

Baharun, H. (2016). Manajemen Kinerja Dalam Meningkatkan Competitive Advantage Pada Lembaga Pendidikan Islam. At-Tajdid: Jurnal Ilmu Tarbiyah, 5(2), 243-262.

Bandung Techno Park (2014), Contract Management. Internal document

Bandung Techno Park (2015), BTP Business Process. Internal document

Bungin, B. (2010). Penelitian Kualitatif. Prenada Media Group, Jakarta.

Cardy, R., \& Leonard, B. (2014). Performance Management: Concepts, Skills and Exercises: Concepts, Skills and Exercises. Routledge.

Christensen, J. F. (1995). Assets profiles for technological innovation. Research Policy, 24(5), 727-745. http://dx.doi.org/10.1016/0048-7333(94)00794-8

Cumming, D., \& Johan, S. (2013). Technology parks and entrepreneurial outcomes around the world. International Journal of Managerial Finance, 9(4), 279-293. https://doi.org/10.1108/IJMF-02-20130018

Dabrowska, J. (2011). Measuring the success of science parks: Performance monitoring and evaluation. XXVIII IASP World Conference on Science and Technology Parks, 1-23.

European Commision, Directorat General for Regional and Urban Policy (2014). Setting up, Managing and Evaluating EU Science \& Technology parks. http://ec.europa.eu/regional_policy/index_en.cfm

Fukugawa, N. (2006). Science parks in Japan and their value-added contributions to new technology-based firms. International Journal of Industrial Organization, 24(2), 381-400. https://doi.org/10.1016/j.ijindorg.2005.07.005

Kaplan, R. S. (2010). Conceptual Foundations of the Balanced Scorecard Conceptual Foundations of the Balanced Scorecard 1.

Koh, F. C. C., Koh, W. T. H., \& Tschang, F. T. (2005). An analytical framework for science parks and technology districts with an application to Singapore. Journal of Business Venturing, 20(2), 217-239. https://doi.org/10.1016/j.jbusvent.2003.12.002

Listiani, T. (2011). Manajemen Kinerja, Kinerja Organisasi Serta Implikasinya Terhadap Kualitas Pelayanan Organisasi Sektor Publik. Jurnal Ilmu Administrasi: Media Pengembangan Ilmu dan Praktek Administrasi, 8(3), 06.

Monck, C., \& Peters, K. (2009). Science parks as an instrument of regional competitiveness: measuring success and impact. IASP 2009 Conference, 1-19.

Multimedia Supercorridor annual Industry report (2015), Malaysia. Retrived online at www.mscmalaysia.my/reporting on 2 April 2018.

Nargesi, G. R., Esfeden, G. A., \& Nargesi, S. R. (2014). The Identification and Ranking of Critical Success Factors of Science and Technology Parks (Case Study: University of Tehran Science and Technology Park). Applied Mathematics in Engineering, Management and Technology, 2(6), 353-363.

Oliva, F. L., \& Kotabe, M. (2019). Barriers, practices, methods and knowledge management tools in startups. Journal of Knowledge Management, 23(9), 1838-1856. https://doi.org/10.1108/JKM-06-2018-0361

Vilà, P. C., \& Pagès, J. L. (2008). Science and technology parks: Creating new environments favourable to innovation. Paradigmes: Economia Productiva $i$ Coneixement, (0), 141-149. Retrieved from http://www.raco.cat/index.php/Paradigmes/article/view/226082

Yan, M.-R., \& Chien, K.-M. (2013). Evaluating the Economic Performance of High-Technology Industry and Energy Efficiency: A Case Study of Science Parks in Taiwan. Energies, 6(2), 973-987. https://doi.org/10.3390/en6020973

Yigitcanlar, T., \& Sarimin, M. (2015). Multimedia Super Corridor, Malaysia. Vine, 45(1), $126-147$. https://doi.org/10.1108/VINE-06-2014-0041

http://www.ukspa.org.uk/our-association/about-us\#sthash.xvO8V14G.dpuf accessed June 30, 2018.

http://www.aurp.net/what-is-a-research-park accessed May 30, 2018.

http://www.iasp.ws/knowledge-bites accessed May 30, 2018.

http://www.iasp.ws/the-role-of-stps-and-innovation-areas accessed May 30, 2018. 